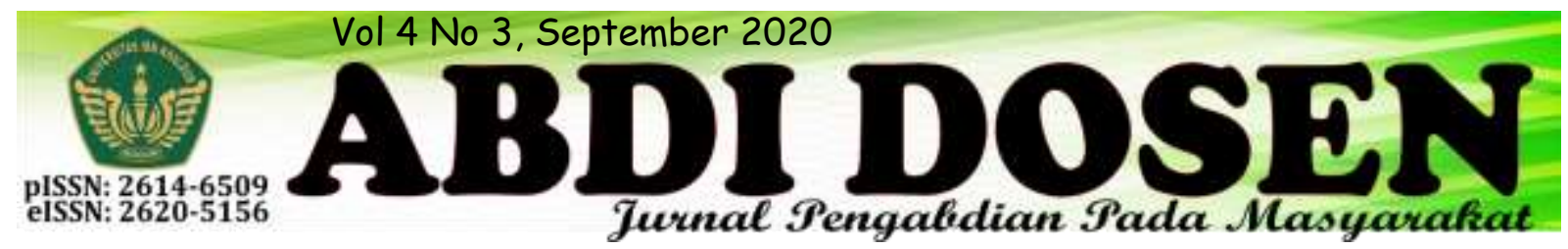

\title{
MENUMBUHKAN KETERAMPILAN WIRAUSAHA IBU-IBU RUMAHAN MELALUI PELATIHAN ENGOLAHAN MAKANAN BERBAHAN DASAR KACANG TANAH DAN KULIT PANGSIT (Kacang Umpet) RT 02/03 DESA HAMBALANG
}

\author{
Nyai Sumiati \\ nyai.sumiati@gmail.com \\ Program Studi Pendidikan Masyarakat, Fakultas Keguruan dan Ilmu Pendidikan \\ Universitas Ibn Khaldun Bogor
}

\begin{abstract}
ABSTRAK
Tujuan dari pengabdian ini adalah untuk memberikan kontribusi dalam peningkatan keterampilan juga pengetahuan dan sikap dalam memasuki dunia wirausaha yang mandiri sebagai salah satu upaya dalam rangka menumbuhkan kecakapan hidup bagi warga Desa Hambalang Rt 02/03 dengan memberikan pendidikan non formal dibidang kewiarusahaan.Pelatihan yang diberikan tidak berupa materi melainkan praktek langsung kepada ibu-ibu rumahan.Praktik yang dilakukan berupa pembuatan makanan yang berbahan dasar kacang tanah dan pangsit.Target luaran dari program pengabdian ini adalah meningkatkan pengetahuan serta keterampilan masyarakat dalam berwirausaha.Dengan pengetahuan kewirausahaan yang mumpuni diharapkan akan mampu menumbuhkan sikap kemandirian yang matang dalam hal ekonomi keluarga,agar biaya hidup dan biaya pendidikan anak anak mereka berjalan lancar,maka mereka perlu diberdayakan untuk perbaiakan kualaitas hidupnya.
\end{abstract}

Kata kunci: Wirausaha,Kemandirian,perbaikan kualitas hidup.Jurnal Program Pengabdian KKN Mandiri

\section{PENDAHULUAN}

Target kegiatan pengabdian kepada masyarakat ini adalah menumbuhkan keterampilan wirausaha di kalangan ibuibu rumahan ditujukan agar mereka bisa membantu perekonomian. Ibu- ibu dituntut untuk memiliki kemandirian dalam hal ekonomi keluarga untuk mendongkrak perbaikan kualitas hidup keluarganya .Namun demikian untuk mencapai kemandirian ekonomi keluarga bukan kondisi yang dapat diciptakan dalam waktu singkat.Kemandirian tersebut perlu ditumbuhkembangkan dari waktu ke waktu.
Keterampilan usaha yang dimiliki oleh sebagian ibu-ibu warga Rt 02/03 Desa Hambalang juga masih tergolong sangat terbatas, karena belum pernah mendapatkan pendampingan dari pihakpihak yang berkompeten dalam bidang kewirausahaan. Padahal jika dilihat dari peluang pemasaran tergolong sangat baik , ibu-ibu rumahan memiliki potensi untuk berkembang dalam kegiatan kewirausahaan yang kreatif sesuai dengan kemampuan yang saat ini mereka miliki . Kendala lain yang dihadapi oleh ibu-ibu rumahan pada umumnya adalah rendahnya 
motivasi wirausaha serta modal untuk mereka mengawali.

Dalam hal ini saya membidik ibuibu rumahan yang berlokasi di Rt 02/03 Desa Hambalang . Alasan saya memilih ibu -ibu rumahan ini dikarenakan mereka ini belum mendapatkan materi kewirausahaan yang akan membantu mereka menghadapi

persaingan yang semakin ketat dalam bidang pekerjaan. Berdasarkan hasil wawancara yang dilakukan terhadap ibuibu rumahan, disimpulkan bahwa sebagian besar dari mereka memiliki kemampuan yang sama dengan ibu - ibu lainnya yang memiliki kemampuan dalam berwirausaha.

Hasil identifikasi menunjukkan ada permasalahan yang dihadapi dan harus dipecahkan jika dilihat dari berbagai sudut pandang yang relevan, yaitu pertama adalah ketrampilan kewirausahaan yang dimiliki masih terbatas. Kedua, belum memiliki target dan sasaran usaha apa yang akan dibuat. Ketiga, belum memiliki keahlian dalam promosi dan pemasaran. Salah satu upaya kami dalam membantu menyelesaikan masalah-masalah yang dihadapi yaitu dengan cara menumbuhkan keterampilan wirausaha di kalangan ibuibu rumahan Rt 02/03 Desa Hambalang berupa pelatihan keterampilan pengolahan makanan berbahan kacang tanah dan kulit pangsit, karena kami lihat usaha ini sedang

\section{METODE PENGABDIAN}

Pengabdian ini dilaksanakan di Rt 02/03 Desa Hambalang. Pelaksanaan pengabdian ini melibatkan beberapa pihak, diantaranya kepala Desa Hambaalang beserta jajaran lainnya dan ibu-ibu rumahtangga yang sekaligus merupakan peserta pelatihan. Metode kegiatan pengabdian masyarakat ini berupa memiliki prospek yang cukup baik, banyak konsumennya, cukup mudah pembuatannya, dan modal yang diperlukan tidak terlalu besar.

Dengan mendapatkan pelatihan keterampilan tersebut diharapkan dapat menjadi sarana bagi ibu -ibu untuk mengasah soft skill dan termotivasi dalam berwirausaha. Pelatihan yang diajarkan tidak hanya sekedar untuk mengembangkan ketrampilan maupun mengasah soft skill saja, akan tetapi dapat digunakan untuk menambah uang belanja, dan mereka akan menjadi lebih mandiri dalam ekonomi keluarga.

Berdasarkan uraian diatas, maka perlu dilakukan pelatihan tentang bagaimana menumbuhkan keterampilan wirausaha melalui pengolahan makanan berbahan dasar kacang tanah dan kulit pangsit terhadap ibu-ibu rumahan Rt 02/03 Desa Hambalang. Kegiatan ini memiliki tujuan untuk memberi pelatihan bagaimana menumbuhkan keterampilan wirausaha melalui pengolahan makanan berbahan dasar kacang tanah dan kulit pangsit terhadap ibu-ibu rumahan Rt 02/03 Desa Hambalang.

Dari penyuluhan ini diharapkan dapat memberikan manfaat Bagi ibu -ibu rumahan memiliki bekal keterampilan wirausaha sehingga terjadinya perbaikan kualitas hidup dalam keluarganya.

pemberian pelatihan melalui praktek keterampilan, diskusi dan Tanya jawab.

Pelaksanaan pengabdian ini dilakukan dengan tiga tahap. Tahap awal pengabdian ini yaitu tahapan persiapan. Pada tahap ini saya pelaksana kegiatan melakukan konsultasi dengan warga $\mathrm{Rt}$ 02/03 dan pihak Desa. Kemudian melakukan survey dan observasi terhadap 
warga Rt 02/03 Desa Hambalang sebagai sasaran dan melakukan koordinasi kepada pihak yang bersangkutan.

Tahap kedua yaitu tahap pelaksanaan kegiatan pengabdian, saya dan rekan rekan yang membantu langsung memberikan praktik keterampilan wirausaha. Setiap peserta pengabdian mendengarkan paparan dari narasumber sekaligus ikut terlibat langsung dalam proses pembuatan. Selama proses pelatihan berlangsung, peserta diberi kesempatan untuk bertanya secara langsung bersamaan setelah itu tim juga memberikan pengalaman bagaimana

\section{HASIL DAN PEMBAHASAN}

Pengabdian kepada masyarakat yang dilaksanakan di Pos Pelayanan Terpadu (posyandu) Mawar Desa Hambalang Kecamatan Citeureup Kabupaten Bogor. Kegiatan ini dilaksanakan sesuai dengan jadwal yang telah ditetapkan dan di sepakati bersama dengan pihak peserta yaitu ibu-ibu warga Rt 02/03 Desa Hambalang . Langkah awal yang dilakukan yaitu persiapan dan permohonan izin kepada Bapak lurah Desa Hambalang dan ketua RW serta RT yang menjadi tujuan pengabdian masyarakat, selanjutnya dilakukan pencarian informasi jumlah peserta dan kegiatan peserta sebelum di adakan pelatihan. Setelah waktu pelaksanaan di sepakati, saya dan rekan dari Prodi Pendidikan Masyarakat menyusun jadwal pelaksanaan dan memulai usaha dan mengasah kreativitas dan inovasi dalam mengelola usaha.

Tahap terakhir yaitu tahap evaluasi. Rencana evaluasi pelaksanaan dengan mengadakan pengamatan langsung di lapangan terhadap peserta pelatihan. Evaluasi yang dilakukan dengan mengecek minat ibu-ibu rumahtangga dalam berwirausaha, mengecek kondisi usaha yaitu keadaan usaha, sudah berjalan atau belum berjalan, prestasi yang dicapai terkait dengan omset, kondisi keuangan, jangkauan pasar, dan jumlah variasi produk.

membuat kesepakatan dengan pihak RW dan RT 02/03 mengenai jadwal pelaksanaan.

Kegiatan pelatihan ini dilaksanakan dalam rangka melaksanakan tugas $\mathrm{KKN}$ Mandiri 2019, yang salah satunya adalah pengabdian kepada masyarakat. Pelatihan ini diberikan untuk ibu-ibu rumahtangga yang tidak memiliki kegiatan lain selain mengurusi rumahtangga, adapun bentuk pelatihan yang dilakukan adalah keterampilan wirausaha ibu-ibu rumahan melalui pelatihan pengolahan makanan berbahan dasar kacang tanah dan kulit pangsit.Pelatihan ini diberikan untuk menambah keterampilan dan pengetahuan bagi ibu-ibu karena keterampilan berwirausaha yang dimiliki oleh ibu-ibu juga masih sangat terbatas. 


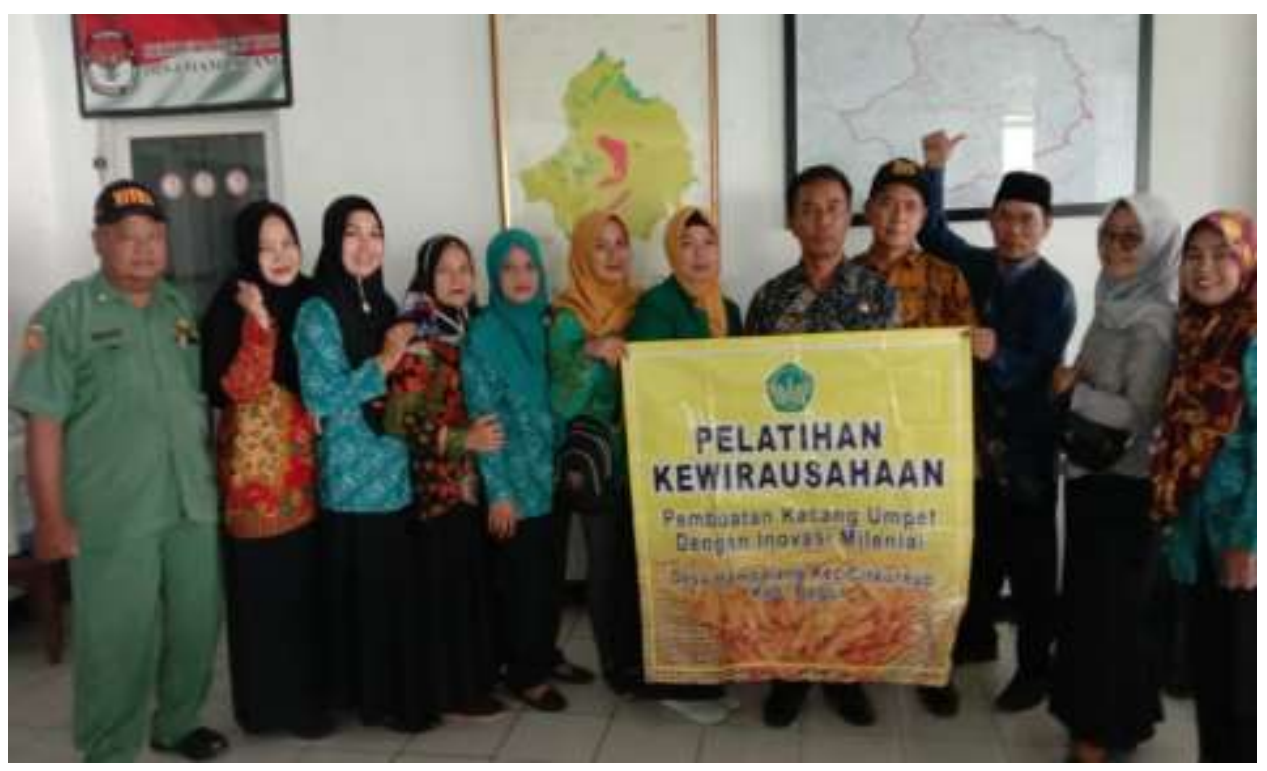

Dalam proses pelaksanaan pelatihan tahapan pertama yang dilakukan dimulai dengan tahapan persiapan, di mana saya sebagai pelaksana dan di bantu oleh rekan mahasiswa juga kader untuk melakukan briefing untuk penyiapan bahan-bahan yang dibutuhkan pada saat pelatihan, membagi tugas masing-masing pembicara, menyiapkan para peserta pelatihan, menyiapkan materi pelatihan yang berhubungan dengan pembimbingan dan praktik berwirausaha.

Kegiatan dilaksanakan sesuai dengan waktu yang telah di sepakati yaitu pada tanggal 10 Oktober 2019 bertempat di ruang Aula Desa Hambalang. Tahapan pelaksaaan kegiatan dimulai dengan bersilaturrahmi dan pelatihan keterampilan pengolahan makanan berbahan dasar kacang tanah dan kulit pangsit. Tahapan pelaksanan selanjutnya yaitu diskusi dan sharing experience bersama ibu-ibu yang sekaligus merupakan peserta pelatihan.Pelatihan diberikan kepada seluruh peserta berupa cara membuat produk makanan yang menarik dan memiliki daya jual di pasaran. Saat pelatihan berlangsung tim juga menyelipkan sedikit penjelasan bagaimana membuat produk yang kreatif dan inovatif serta alasan kenapa produk ini yang dipilih dalam praktik pelatihan. Peserta juga di berikan kesempatan untuk bertanya seputar produk maupun yang berkaitan dengan pemasaran produk. 


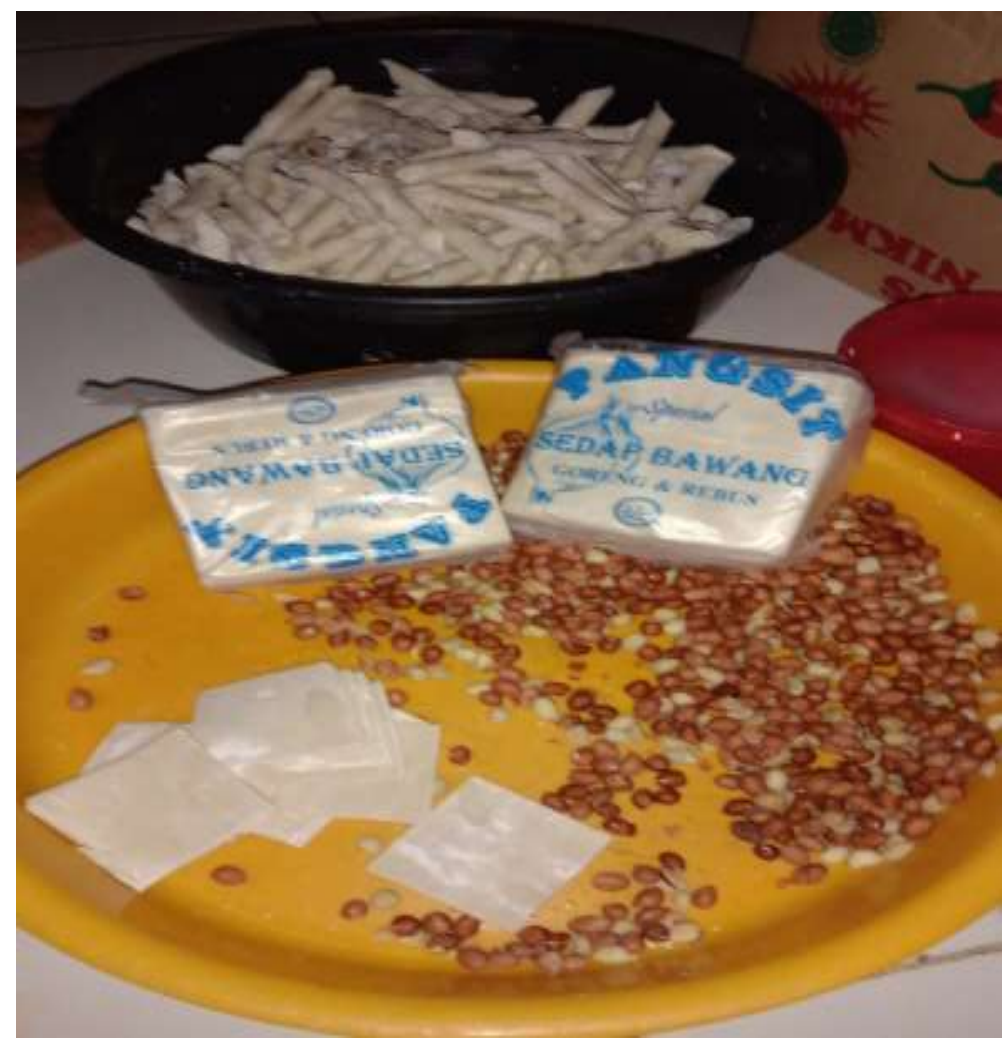

Proses pembuatan kacang umpet dan bahan bahan yang dibutuhkan adalah

1. Kacang tanah

2. Kulit pangsit

3. Tepung sagu

4. Bumbu /rempah rempah

5. Penyedap rasa

6. Minyak goreng

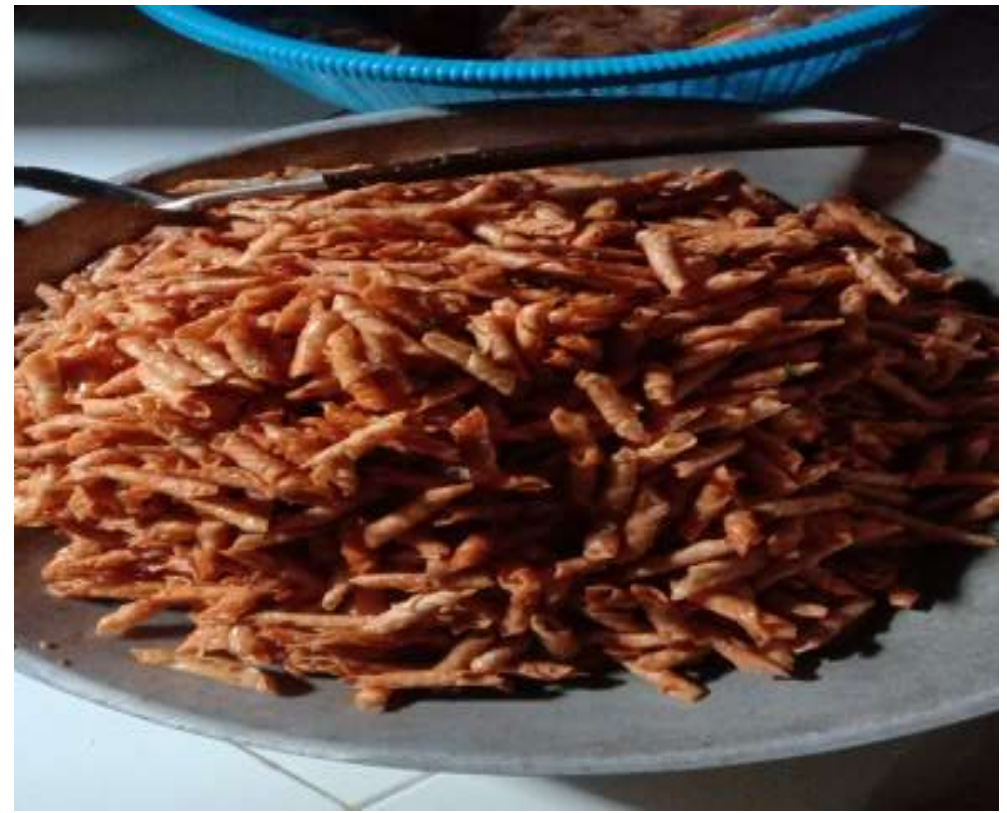

Gambar kegiatan praktik 


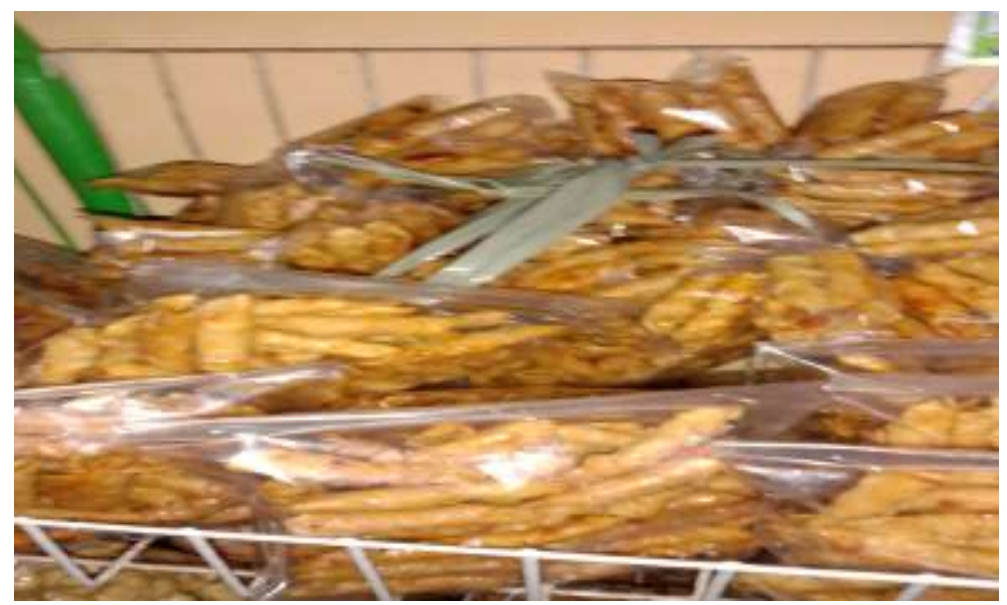

Gambar kegiatan praktik tahap akhir (packing)

Evaluasi pada tahap pertama telah sesuai dengan indikator dan rancangan evaluasi diperoleh data sebagai berikut:

1. Jumlah peserta yang hadir sebanyak 15 orang sehingga tingkat kehadiran mencapai $100 \%$.

2. Peserta sangat terlihat antusias selama mengikuti kegiatan hingga pelatihan selesai
3. Setiap peserta aktif mengutarakan pertanyaan dan diskusi dalam pemecahan masalah dan kendala yang dialami pada saat memulai dan menjalankan usaha.

4. Setelah dilakukan pelatihan diharapkan para ibu rumahtangga Rt 02/03 Desa Hambalang memiliki karakteristik wirausahawan yang tangguh dan siap berkompetisi sekaligus bersaing dalam bisnis yang sama.

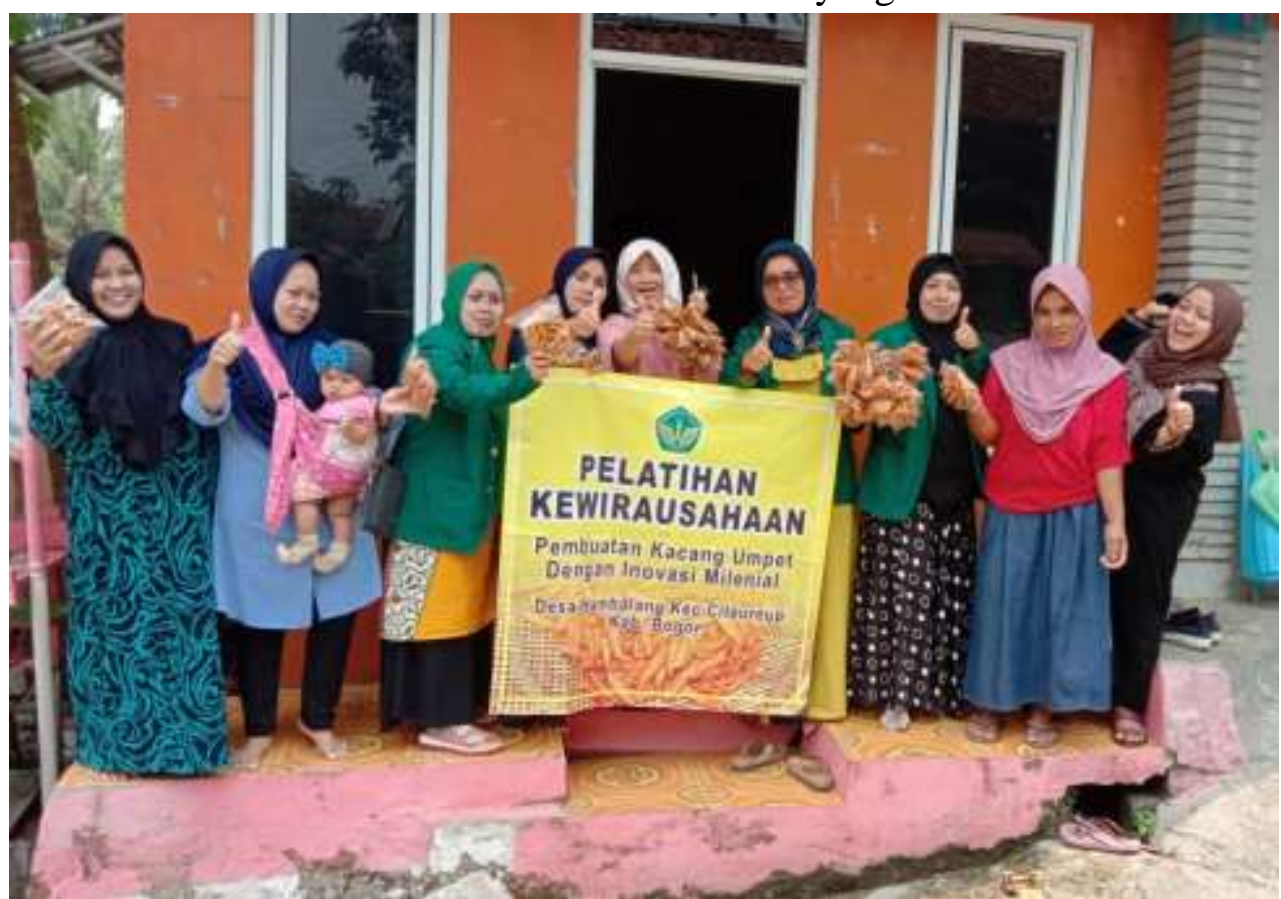

Secara umum evaluasi yang dilakukan terlaksana dengan baik, dan peserta dan pengasuh panti asuhan berharap kegiatan ini terus berkelanjutan kedepannya dengan variasi produk yang berbeda dan lebih inovatif. 


\section{SIMPULAN}

Pelatihan yang dilakukan pada akhirnya mampu menumbuhkan intensi mereka untuk berwirausaha karena proses kegiatan pembuatan makanan berbahan dasar kacang tanah dan kulit pangsit ini mudah diingat dan mudah dilakukan sehingga setelah kegiatan pelatihan ini berakhir peserta mampu membuat produk itu sendiri dan bersedia menjual produk itu sebagai usaha dalam menumbuhkan jiwa wirausaha. Peserta merespon kegiatan pelatihan ini dengan baik. Mereka merasa senang dan nyaman selama mengikuti kegiatan pelatihan. Mereka juga mampu mengikuti setiap arahan dari pemateri dan sangat antusias mengikuti kegiatan pelatihan ini mulai dari awal hingga akhir pelatihan, hal ini dikarenakan sangat jarang mereka mendapatkan kegiatan dalam bentuk praktek yang dapat menambah

\section{DAFTAR PUSTAKA}

Buchari Alma. (2016). Kewirausahaan. Bandung: Alfabeta. Anggota Ikatan Penerbitan Indonesia.

Buchari Alma. (2016). Kewirausahaan. Bandung: Alfabeta. Anggota Ikatan Penerbitan Indonesia.

Gerry, sholeh. (2017),). Pemberdayaan remaja panti asuhan melalui pembuatan nugget guna menumbuhkan minat berwirausaha. ABDIPAMAS, 1(1), 118-127.

Jannah, Kusniasih Miftakhul. 2014. Pertumbuhan Wirausaha Indonesia Masih Terbatas. Online.

(m.okezone.com/read/2014/11/21/320/106 9038/pertumbuhan-wirausahaindonesia-masih-terbatas). ketrampilan dan melatih kemandirian melalui pelatihan.

\section{UCAPAN TERIMAKASIH}

Ucapan terimakasih kami ucapkan kepada Lembaga Penelitian dan Pengabdian Masyarakat (LPPM)Universitas Ibn Kholdun Bogor atas kesempatan yang diberikan pada saya untuk mengikuti Program KKN 2019 secara mandiri dengan melakukan pengabdian kepada masyarakat. Serta uacapan terimakasih saya ucapkan kepada pihak Desa Hambalang yang telah mendukung dan menyediakan fasilitas agar terselenggaranya kegiatan ini serta rekan mahasiswa yang terlibat langsung mendukung kelancaran kegiatan pengabdian ini.

Kasmir. (2017). Kewirausahaan. Jakarta : Penerbit Rajawali Pers

Kottler Philip.G Amstrong. (2012). Manajemen Pemasaran.Edisi 13, jilid 1. Jakarta. Penerbit Erlangga.

Jurnal Pengabdian Untuk Mu NegeRI, VOL.2 No.2, NOVEMBER 2018

Prasetya, E. (2018). Pemberdayaan Masyarakat Tentang Kesehatan, Pendidikan dan Kreatifitas. Abdi Dosen: Jurnal Pengabdian Pada Masyarakat 2 (1), 19-25.

LP2M. (2018). Pedoman Penulisan Penelitian dan Pengabdian pada Masyarakat Universitas Ibn Kholdun Bogor 